\title{
Computer-Aided Rational Drug Design: A Novel Agent (SR13668) Designed to Mimic the Unique Anticancer Mechanisms of Dietary Indole-3-Carbinol to Block Akt Signaling
}

\author{
Wan-Ru Chao, Dawn Yean, Khalid Amin, Carol Green and Ling Jong* \\ SRI International, Menlo Park, California
}

\section{Table of Contents}

Experimental section

Elemental analysis

S6

Computational Analyses

S6

Protocols for cell proliferation assays

S6

Western blot analysis

S7

Figure 1S. Effect of SR13668 on serum-stimulated

Akt phosphorylation in PC-3 prostate cancer cells

Protocol for tumor xenografts studies 


\section{Experimental Section}

General. ${ }^{1} \mathrm{H}$ and ${ }^{13} \mathrm{C}$ NMR spectra were recorded on a Varian Gemini $300 \mathrm{MHz}$ spectrometer (300 MHz and $75 \mathrm{MHz}$, respectively) and are internally referenced to chloroform at $\delta 7.27$. Data for ${ }^{1} \mathrm{H}$ NMR are reported as follows: chemical shift $(\delta \mathrm{ppm})$, multiplicity ( $\mathrm{s}=$ singlet, $\mathrm{d}=$ doublet, $\mathrm{t}=$ triplet, $\mathrm{q}=$ quartet, $\mathrm{m}=$ multiplet $)$, coupling constant $(\mathrm{Hz})$, integration, and assignment. Data for ${ }^{13} \mathrm{C}$ are reported in terms of chemical shift. IR spectra were recorded on a Perkin-Elmer 1610 spectrometer and are reported in terms of frequency of absorption $\left(\mathrm{cm}^{-1}\right)$. Mass spectra were obtained using a ThermoFinnigan LCQ Duo LC/MS/MS instrument and an electrospray ionization probe. Thin-layer chromoatgraphy was run on Analtech Uniplate silica gel TLC plates.

\section{General procedures used for the syntheses of indole analogs.}

(a) Boc Deprotection. To a solution of Boc-protected indole $(6.24 \mathrm{mmol})$ in $\mathrm{CH}_{2} \mathrm{Cl}_{2}(50 \mathrm{~mL})$ was added $\mathrm{CF}_{3} \mathrm{CO}_{2} \mathrm{H}(10 \mathrm{~mL})$ and stirred for overnight under argon. The solution was diluted with toluene $(30 \mathrm{~mL})$ and evaporated to give a solid, which was then subjected to recrystallization.

(b) Halogen-metal exchange and nuclei addition. To a solution of $1.7 \mathrm{Mt}$-BuLi in pentane $(22.5 \mathrm{mmol})$ in THF $(70 \mathrm{~mL})$ at $-100{ }^{\circ} \mathrm{C}$ under argon was added $\mathrm{N}$-protected dibromoindole (5.11 mmol) in THF $(10 \mathrm{~mL})$, and stirred for $10 \mathrm{~min}$. Excess amount of $\mathrm{ClCO}_{2} \mathrm{CH}_{2} \mathrm{CH}_{3}(5 \mathrm{~mL})$ was added and the mixture was stirred for $20 \mathrm{~min}$. The reaction mixture was poured into saturated aqueous $\mathrm{NaHCO}_{3}$ and extracted with 50\% EtOAc/hexane. The combined organic extracts were dried $\left(\mathrm{MgSO}_{4}\right)$, filtered, and concentrated. The crude products were subjected to chromatography.

Synthesis of 6-Ethoxycarbonyloxy-5,7-dihydro-indolo[2,3-b]carbazole (10, SR13650).

3,3'-Diindolylmethane (2). Indole-3-carbinol (21) (1.0 g, $6.79 \mathrm{mmol})$ in 10\% aqueous $\mathrm{NaOH}$ solution $(100 \mathrm{~mL})$ was refluxed for $1 \mathrm{~h}$. The solution was cooled, neutralized with carbon dioxide and the white precipitate was collected by filtration, which was then crystallized from toluene to yield 2 as a white solid $(0.65 \mathrm{~g}, 77 \%):{ }^{1} \mathrm{H} \mathrm{NMR}\left(300 \mathrm{MHz}, \mathrm{CDCl}_{3}\right) \delta 4.26\left(\mathrm{~s}, 2, \mathrm{CH}_{2}\right)$, 6.94 (m, 2, PyH), 7.11 (m, 2, ArH), 7.21 (m, 2, ArH), 7.36 (m, 2, ArH), 7.64 (m, 2, ArH), 7.86 (br.s, 2, NH).

1,1'-DiBOC-3,3'-diindolylmethane (22). To a solution of $2(2.0 \mathrm{~g}, 8.12 \mathrm{mmol})$ and ( $t$ $\mathrm{BuOOC})_{2} \mathrm{O}(3.9 \mathrm{~g}, 17.87 \mathrm{mmol})$ in THF $(20 \mathrm{~mL})$ was added a catalytic amount of DMAP and stirred for overnight under argon. The solvent was evaporated to give a crude product. Flash chromatography (3\% EtOAc/hexane) yielded 22 as a white solid (3.44 g, 95\%): ${ }^{1} \mathrm{H}$ NMR (300 $\left.\mathrm{MHz}, \mathrm{CDCl}_{3}\right) \delta 1.65\left(\mathrm{~s}, 18, \mathrm{OC}\left(\mathrm{C}_{3}\right)_{3}\right), 4.09$ (s, 2, $\left.\underline{\mathrm{CH}}_{2}\right), 7.21$ (m, 2, ArH), 7.31 (m, 2, ArH), 7.38 (s, 2, PyH), 7.53 (m, 2, ArH), 8.12 (br.d, $J=8.6$ Hz, 2, ArH).

6-Ethoxycarbonyloxy-5,7-dihydro-indolo[2,3-b]carbazole (10, SR13650). To a solution of 2,2,6,6-tetramethylpiperidine $(1.7 \mathrm{~mL}, 10 \mathrm{mmol})$ in THF $(25 \mathrm{~mL})$ at $-78{ }^{\circ} \mathrm{C}$ under argon was added $1.6 \mathrm{M} \mathrm{n}$-BuLi $(9.4 \mathrm{mmol})$ in hexane $(6.6 \mathrm{~mL})$, and warmed to $0{ }^{\circ} \mathrm{C}$ for $15 \mathrm{~min}$. After the 
reaction mixture was recooled to $-78{ }^{\circ} \mathrm{C}, 22(0.7 \mathrm{~g}, 1.57 \mathrm{mmol})$ in THF $(5 \mathrm{~mL})$ was added slowly, and stirring was continued for $30 \mathrm{~min}$ before $\mathrm{ClCO}_{2} \mathrm{CH}_{2} \mathrm{CH}_{3}(2 \mathrm{~mL})$ was added. The reaction mixture was stirred for $2 \mathrm{~h}$ at $-78{ }^{\circ} \mathrm{C}$ and poured into saturated $\mathrm{NaHCO}_{3}$ and extracted with $50 \%$ EtOAc/hexane. The combined organic extracts were dried $\left(\mathrm{MgSO}_{4}\right)$, filtered, and concentrated to afford a crude mixture, which was then deprotected using the general procedure. Flash chromatography (20\% EtOAc/hexane) yielded $10(0.39 \mathrm{~g}, 72 \%)$ as a white solid: ${ }^{1} \mathrm{H}$ NMR $\left(300 \mathrm{MHz}, \mathrm{CDCl}_{3}\right) \delta 1.51\left(\mathrm{t}, J=7.1 \mathrm{~Hz}, 3, \mathrm{CO}_{2} \mathrm{CH}_{2} \mathrm{CH}_{3}\right), 4.49$ (q, $J=7.1 \mathrm{~Hz}, 2, \mathrm{CO}_{2} \underline{\mathrm{C}}_{2} \mathrm{CH}_{3}$ ), 7.28 (m, 2, ArH), 7.41 (m, 2, ArH), 7.46 (br.d, $J=7.8$ Hz, 2, ArH), 8.16 (d, J= $7.7 \mathrm{~Hz}, 2$, ArH), 8.21 (br.s, 2, NH), 8.60 (s, 1, ArH). Anal. $\left(\mathrm{C}_{21} \mathrm{H}_{16} \mathrm{~N}_{2} \mathrm{O}_{3}\right) \mathrm{C}, \mathrm{H}, \mathrm{N}$

\section{Synthesis of 2,10-Dicarbethoxy-6-ethoxycarbonyloxy-5,7-dihydro-indolo $[2,3-b]$ carbazole} (36, SR13661).

5,5'-Dibromo-3,3'-diindolylmethane (29). To a well-mixed suspension of 5-bromoindole (28) $(1 \mathrm{~kg})$ in $1.2 \%$ trifluoroacetic acid in $5 \mathrm{~L}$ THF solution $(4.5 \mathrm{~kg})$ is added $37 \% \mathrm{CH}_{2} \mathrm{O} / \mathrm{H}_{2} \mathrm{O}(627 \mathrm{~mL})$ and heated to $30-35^{\circ} \mathrm{C}$ for around 24 hours. ( $\left.\mathrm{SM}<5 \%\right) 2.0 \mathrm{Kg}$ of water is added to reaction mixture and the aqueous layer is removed. $1.0 \mathrm{Kg}$ of $5-10 \% \mathrm{NaOH}$ solution is added to reaction mixture and the aqueous layer is removed. The organic layer is added $1100 \mathrm{~mL}$ of aqueous $\mathrm{NaOH}(35-40 \%)$. The reaction mixture is stirred NLT $5 \mathrm{~h}$ and the aqueous layer is removed. The organic layer is washed with ammonium chloride and sodium chloride solution and collected organic layer and concentrated to give brown oil, which is then diluted with toluene and the solvent is evaporated and toluene/heptane $(\mathrm{v} / \mathrm{v}=1 / 1)$ cooled to $-5^{\circ} \mathrm{C}$. The mixture is filtered and washed with toluene/heptane to give a solid, which is dried under reduced pressure at $40^{\circ} \mathrm{C}$ to give 29 as a white solid (50-65\%, purity>90\%): ${ }^{1} \mathrm{H} \mathrm{NMR}\left(300 \mathrm{MHz}, \mathrm{CDCl}_{3}\right) \delta 4.14\left(\mathrm{~s}, 2, \mathrm{CH}_{2}\right)$, $6.96(\mathrm{~m}, 2, \mathrm{PyH}), 7.24$ (d, $J=8.0 \mathrm{~Hz}, 2$, ArH), 7.28 (dd, $J=1.5,8.0 \mathrm{~Hz}, 2, \mathrm{ArH}), 7.71$ (d, $J=1.5$ $\mathrm{Hz}, 2, \mathrm{ArH}), 7.97$ (br.s, 2, NH).

1,1'-DiBOC-5,5'-dibromo-3,3'-diindolylmethane (30). To a solution of 5,5'-dibromo-3,3'diindolylmethane (29) $(7.3 \mathrm{~g}, 18.06 \mathrm{mmol})$ and $(t \text {-BuOOC })_{2} \mathrm{O}(8.7 \mathrm{~g}, 39.8 \mathrm{mmol})$ in THF $(100$ $\mathrm{mL}$ ) was added a catalytic amount of dimethylaminopyridine (DMAP) and stirred for overnight under argon. The solvent was evaporated to give a crude product. Flash chromatography (5\% EtOAc/hexane) yielded 30 as a white solid (10.3 g, 94\%): ${ }^{1} \mathrm{H}$ NMR $\left(300 \mathrm{MHz}, \mathrm{CDCl}_{3}\right) \delta 1.65$ (s, 18, OC( $\left(\underline{\mathrm{H}}_{3}\right)_{3}, 4.00$ (s, 2, $\left.\underline{\mathrm{CH}}_{2}\right), 7.34$ (s, 2, PyH), 7.42 (dd, J = 2.0, 8.2 Hz, 2, ArH), 7.63 (d, $J$ $=2.0 \mathrm{~Hz}, 2, \mathrm{ArH}), 8.01(\mathrm{~d}, J=8.2 \mathrm{~Hz}, 2, \mathrm{ArH})$.

2,10-Dibromo-6-ethoxycarbonyloxy-5,7-diBOC-indolo[2,3-b]carbazole (38). To a solution of 2,2,6,6-tetramethylpiperidine $(20.3 \mathrm{~g}, 143.5 \mathrm{mmol})$ in THF $(300 \mathrm{~mL})$ at $-78{ }^{\circ} \mathrm{C}$ under argon was added 1.6 M n-BuLi (130.4 mmol) in hexane $(81.5 \mathrm{~mL})$, and warmed to $0{ }^{\circ} \mathrm{C}$ for $15 \mathrm{~min}$. After the reaction mixture was recooled to $-78{ }^{\circ} \mathrm{C}, 30(7.88 \mathrm{~g}, 13.04 \mathrm{mmol})$ in THF $(15 \mathrm{~mL})$ was added slowly, and stirring was continued for $30 \mathrm{~min}$ before $\mathrm{ClCO}_{2} \mathrm{CH}_{2} \mathrm{CH}_{3}(30 \mathrm{~mL})$ was added. The mixture was slowly warmed to $-10{ }^{\circ} \mathrm{C}$ during $2 \mathrm{~h}$. The reaction mixture was poured into saturated $\mathrm{NaHCO}_{3}$ and extracted with $50 \%$ EtOAc/hexane. The combined organic extracts were dried $(\mathrm{MgSO} 4)$, filtered, and concentrated to afford a crude product. Flash chromatography (5\% EtOAc/hexane) yielded 38 as a white solid (8.6 g, 94\%): ${ }^{1} \mathrm{H}$ NMR $\left(300 \mathrm{MHz}, \mathrm{CDCl}_{3}\right) \delta 1.39(\mathrm{t}, J$ 
$\left.=7.1 \mathrm{~Hz}, 3, \mathrm{CO}_{2} \mathrm{CH}_{2} \underline{\mathrm{CH}}_{3}\right), 1.74\left(\mathrm{~s}, 18, \mathrm{OC}\left(\mathrm{CH}_{3}\right)_{3}\right), 4.33\left(\mathrm{q}, J=7.1 \mathrm{~Hz}, 2, \mathrm{CO}_{2} \mathrm{C}_{2} \mathrm{CH}_{3}\right), 7.54$ (dd, $J=2.0,9.1 \mathrm{~Hz}, 2$, ArH), 7.92 (d, $J=9.1 \mathrm{~Hz}, 2, \mathrm{ArH}), 8.15$ (d, $J=2.0 \mathrm{~Hz}, 2, \mathrm{ArH}), 8.31$ (s, $1, \mathrm{ArH})$.

2,10-Dicarbethoxy-6-ethoxycarbonyloxy-5,7-dihydro-indolo[2,3-b]carbazole (36, SR13661). To a solution of $1.7 \mathrm{M} t$-BuLi in pentane $(32.3 \mathrm{~mL}, 54.8 \mathrm{mmol})$ in THF $(200 \mathrm{~mL})$ at $-100{ }^{\circ} \mathrm{C}$ under argon was added $38(7.0 \mathrm{~g}, 9.97 \mathrm{mmol})$ in THF $(20 \mathrm{~mL})$, and stirred for $10 \mathrm{~min}$. $\mathrm{ClCO}_{2} \mathrm{CH}_{2} \mathrm{CH}_{3}(30 \mathrm{~mL})$ was added and the mixture was slowly warmed to $-10{ }^{\circ} \mathrm{C}$ during $2.5 \mathrm{~h}$. The reaction mixture was poured into saturated aqueous $\mathrm{NH}_{4} \mathrm{Cl}$ and extracted with $50 \%$ EtOAc/hexane. The combined organic extracts were dried $\left(\mathrm{MgSO}_{4}\right)$, filtered, and concentrated to afford a crude product. Flash chromatography $(10 \% ; 20 \%$ EtOAc/hexane) yielded 1, 1'diBOC-2,10-dicarbethoxy-6-ethoxycarbonyloxy-indolo[2,3-b]carbazole 42 as a white solid (6.1 g, 89\%). 42 ( $4.3 \mathrm{~g}, 6.24 \mathrm{mmol})$ was deprotected using the general procedure. Recrystallization (ethyl acetate/hexane) afforded 36 as a white solid $(2.8 \mathrm{~g}, 92 \%):{ }^{1} \mathrm{H}$ NMR $\left(300 \mathrm{MHz}, \mathrm{CDCl}_{3}\right) \delta$ $1.50\left(\mathrm{~m}, 9, \mathrm{CO}_{2} \mathrm{CH}_{2} \underline{\mathrm{CH}}_{3}\right), 4.48\left(\mathrm{~m}, 6, \mathrm{CO}_{2} \underline{\mathrm{CH}}_{2} \mathrm{CH}_{3}\right), 7.46$ (d, $\left.J=8.3 \mathrm{~Hz}, 2, \mathrm{ArH}\right), 8.16$ (dd, $J=$ 1.5, 8.3 Hz, 2, ArH), 8.49 (br.s, 2, NH), 8.71 (s, 1, ArH), 8.89 (d, J=1.5 Hz, 2, ArH). Anal. $\left(\mathrm{C}_{27} \mathrm{H}_{24} \mathrm{~N}_{2} \mathrm{O}_{7}\right) \mathrm{C}, \mathrm{H}, \mathrm{N}$

Synthesis of 2,10-Dicarbethoxy-6-heptafluoropropyl-5,7-dihydro-indolo[2,3-b]carbazole (36, SR13667).

2,10-Dibromo-6-heptafluoropropyl-5,7-diBOC-indolo[2,3-b]carbazole (39). To a solution of 2,2,6,6-tetramethylpiperidine $(8.9 \mathrm{~g}, 63 \mathrm{mmol})$ in THF $(180 \mathrm{~mL})$ at $-78{ }^{\circ} \mathrm{C}$ under argon was added $1.6 \mathrm{M} n$-BuLi $(60 \mathrm{mmol})$ in hexane $(37.5 \mathrm{~mL})$, and warmed to $0{ }^{\circ} \mathrm{C}$ for $15 \mathrm{~min}$. After the reaction mixture was recooled to $-78^{\circ} \mathrm{C}, \mathbf{3 0}(4 \mathrm{~g}, 6.62 \mathrm{mmol})$ in $\mathrm{THF}(20 \mathrm{~mL})$ was added slowly, and stirring was continued for $30 \mathrm{~min}$ before heptafluorobutyric anhydride $(25 \mathrm{~g})$ was added. After $10 \mathrm{~min}$, the mixture was warmed to $0{ }^{\circ} \mathrm{C}$ for $30 \mathrm{~min}$. The reaction mixture was poured into saturated $\mathrm{NaHCO}_{3}$ and extracted with ethyl acetate. The combined organic extracts were dried (MgSO4), filtered, and concentrated to afford a crude product. Flash chromatography (5\% EtOAc/hexane) yielded 39 contaminated with excess reagent. Recrystallization (ethyl acetate/hexane) afforded 39 as a white solid (4.1 g, 79\%): ${ }^{1} \mathrm{H} \mathrm{NMR}\left(300 \mathrm{MHz}, \mathrm{CDCl}_{3}\right) \delta 1.68(\mathrm{~s}$, 18, $\left.\mathrm{OC}\left(\mathrm{CH}_{3}\right)_{3}\right), 7.60(\mathrm{dd}, J=2.0,8.8 \mathrm{~Hz}, 2, \mathrm{ArH}), 7.98(\mathrm{~d}, J=8.8 \mathrm{~Hz}, 2, \mathrm{ArH}), 8.18(\mathrm{~d}, J=2.0$ $\mathrm{Hz}, 2, \mathrm{ArH}), 8.55$ (s, 1, ArH).

2,10-Dicarbethoxy-6-heptafluoropropyl-5,7-diBOC-indolo[2,3-b]carbazole (43). The general procedure (b) was used to prepare 43 from 39 (4.0 g, 5.11 mmol), $1.7 \mathrm{M} \mathrm{t}$-BuLi in pentane $(15 \mathrm{~mL}, 25.56 \mathrm{mmol})$, and $\mathrm{ClCO}_{2} \mathrm{CH}_{2} \mathrm{CH}_{3}(5 \mathrm{~mL})$. Flash chromatography (10\% EtOAc/ hexane) yielded 43 as a white solid (3.58 g, 91\%): ${ }^{1} \mathrm{H} \mathrm{NMR}\left(300 \mathrm{MHz}, \mathrm{CDCl}_{3}\right) \delta 1.49(\mathrm{t}, J=7.0$ $\left.\mathrm{Hz}, 6, \mathrm{CO}_{2} \mathrm{CH}_{2} \underline{\mathrm{C}}_{3}\right), 1.70\left(\mathrm{~s}, 18, \mathrm{OC}\left(\mathrm{C}_{3}\right)_{3}\right), 4.48$ (q, $\left.J=7.0 \mathrm{~Hz}, 4, \mathrm{CO}_{2} \mathrm{C}_{2} \mathrm{CH}_{3}\right), 8.13$ (d, $J=$ $8.8 \mathrm{~Hz}, 2, \mathrm{ArH}), 8.23$ (dd, $J=1.7,8.8 \mathrm{~Hz}, 2, \mathrm{ArH}), 8.80$ (m, 3, ArH).

2,10-Dicarbethoxy-6-heptafluoropropyl-5,7-dihydro-indolo[2,3-b]carbazole (36, SR13667). 43 (3.58 g, $4.66 \mathrm{mmol}$ ) was deprotected using the general procedure. Recrystallization (ethyl acetate/hexane) afforded 36 as a white solid (2.6 g, 98\%): ${ }^{1} \mathrm{H}$ NMR $\left(300 \mathrm{MHz}, \mathrm{CDCl}_{3}\right) \delta 1.50(\mathrm{t}$, 
$\left.J=7.3 \mathrm{~Hz}, 6, \mathrm{CO}_{2} \mathrm{CH}_{2} \mathrm{C}_{3}\right), 4.47$ (q, $\left.J=7.3 \mathrm{~Hz}, 4, \mathrm{CO}_{2} \mathrm{CH}_{2} \mathrm{CH}_{3}\right), 7.53$ (d, $\left.J=8.5 \mathrm{~Hz}, 2, \mathrm{ArH}\right)$, 8.17 (dd, $J=1.2,8.5 \mathrm{~Hz}, 2$, ArH), 8.91 (d, $J=1.2 \mathrm{~Hz}, 2$, ArH), 9.02 (s, 1, ArH), 9.43 (br.s, 2, $\mathrm{NH})$. Anal. $\left(\mathrm{C}_{27} \mathrm{H}_{19} \mathrm{~F}_{7} \mathrm{~N}_{2} \mathrm{O}_{4}\right) \mathrm{C}, \mathrm{H}, \mathrm{N}$

Synthesis of 2,10-Dicarbethoxy-6-methoxy-5,7-dihydro-indolo[2,3-b]carbazole (37, SR13668).

2,10-Dibromo-6-hydroxy-5,7-diBOC-indolo[2,3-b]carbazole (40). To a solution of 2,2,6,6tetramethylpiperidine $(7.72 \mathrm{~g}, 54.7 \mathrm{mmol})$ in THF $(180 \mathrm{~mL})$ at $-78{ }^{\circ} \mathrm{C}$ under argon was added 1.6 $\mathrm{M} \mathrm{n}$-BuLi $(49.7 \mathrm{mmol})$ in hexane $(31 \mathrm{~mL})$, and warmed to $0{ }^{\circ} \mathrm{C}$ for $15 \mathrm{~min}$. After the reaction mixture was recooled to $-78{ }^{\circ} \mathrm{C}, \mathbf{3 0}(3 \mathrm{~g}, 4.97 \mathrm{mmol})$ in THF $(20 \mathrm{~mL})$ was added slowly, and stirring was continued for $30 \mathrm{~min}$ before $\mathrm{ClCO}_{2} \mathrm{CH}_{2} \mathrm{CH}_{3}(15 \mathrm{~mL})$ was added. After $30 \mathrm{~min}$, $\mathrm{CH}_{3} \mathrm{CO}_{2} \mathrm{H}(10 \mathrm{~mL})$ in THF $(10 \mathrm{~mL})$ was added to the mixture at $-78{ }^{\circ} \mathrm{C}$ and stirred for $10 \mathrm{~min}$. The reaction mixture was poured into $\mathrm{H}_{2} \mathrm{O}$ and the organic layer was washed with water; brine and concentrated to give a solid. Recrystallization (ethyl acetate/hexane) afforded $\mathbf{4 0}$ as a white solid (2.9 g, 92\%): ${ }^{1} \mathrm{H}$ NMR (300 MHz, $\left.\mathrm{CDCl}_{3}\right) \delta 1.74\left(\mathrm{~s}, 18, \mathrm{OC}\left(\mathrm{C}_{3}\right)_{3}\right), 7.54(\mathrm{dd}, J=2.0,8.8$ $\mathrm{Hz}, 2, \mathrm{ArH}), 7.92$ (d, $J=8.8 \mathrm{~Hz}, 2, \mathrm{ArH}), 7.97$ (s, 1, ArH), 8.12 (d, J=2.0 Hz, 2, ArH), 11.21 (s, $1, \mathrm{OH})$.

2,10-Dibromo-6-methoxy-5,7-diBOC-indolo[2,3-b]carbazole (41). To a suspension of phenol 40 (2.3 g, $3.65 \mathrm{mmol})$ in DMF/THF $(20 / 20 \mathrm{~mL})$ at room temperature under argon was added $\mathrm{CH}_{3} \mathrm{I}(1.1 \mathrm{~mL}, 17.7 \mathrm{mmol})$ and excess amount of $\mathrm{K}_{2} \mathrm{CO}_{3}$, and stirred for overnight. The reaction mixture was diluted with $20 \%$ EtOAc/hexane and washed with water (4 times) and brine. The combined organic extracts were dried (MgSO4), filtered, and concentrated to afford a crude product. Flash chromatography (3\% EtOAc/hexane) yielded 41 as a white solid (1.04 g, 91\%): ${ }^{1} \mathrm{H}$ NMR $\left(300 \mathrm{MHz}, \mathrm{CDCl}_{3}\right) \delta 1.75\left(\mathrm{~s}, 18, \mathrm{OC}\left(\mathrm{CH}_{3}\right)_{3}\right), 3.79\left(\mathrm{~s}, 3, \mathrm{OCH}_{3}\right), 7.55(\mathrm{dd}, J=2.0,8.8$ $\mathrm{Hz}, 2, \mathrm{ArH}), 7.97$ (d, $J=8.8 \mathrm{~Hz}, 2, \mathrm{ArH}), 8.14$ (d, $J=2.0 \mathrm{~Hz}, 2, \mathrm{ArH}), 8.16$ (s, 1, ArH).

2,10-Dicarbethoxy-6-methoxy-5,7-diBOC-indolo[2,3-b]carbazole (44). The general procedure (b) was used to prepare $\mathbf{4 4}$ from $41(2.3 \mathrm{~g}, 3.57 \mathrm{mmol}), 1.7 \mathrm{M} t$-BuLi in pentane (10.5 $\mathrm{mL}, 17.8 \mathrm{mmol})$, and $\mathrm{ClCO}_{2} \mathrm{CH}_{2} \mathrm{CH}_{3}(15 \mathrm{~mL})$. Flash chromatography (10\% EtOAc/hexane) yielded 44 as a white solid (2.1 g, 93\%): ${ }^{1} \mathrm{H}$ NMR $\left(300 \mathrm{MHz}, \mathrm{CDCl}_{3}\right) \delta 1.49(\mathrm{t}, J=7.0 \mathrm{~Hz}, 6$, $\left.\mathrm{CO}_{2} \mathrm{CH}_{2} \underline{\mathrm{C}}_{3}\right), 1.75$ (s, 18, OC( $\left.\left(\underline{\mathrm{H}}_{3}\right)_{3}\right), 3.81\left(\mathrm{~s}, 3, \mathrm{OCH}_{3}\right), 4.47$ (q, J=7.0 Hz, 4, $\left.\mathrm{CO}_{2} \mathrm{C}_{2} \mathrm{CH}_{3}\right)$, $8.11(\mathrm{~d}, J=8.8 \mathrm{~Hz}, 2, \mathrm{ArH}), 8.19$ (dd, $J=1.8,8.8 \mathrm{~Hz}, 2$, ArH), 8.40 (s, 1, ArH), 8.77 (d, $J=1.8$ $\mathrm{Hz}, 2, \mathrm{ArH})$.

2,10-Dicarbethoxy-6-methoxy-5,7-dihydro-indolo[2,3-b]carbazole (37, SR13668). 44 (2.1 g, $3.33 \mathrm{mmol}$ ) was deprotected using the general procedure. Recrystallization (ethyl acetate/hexane) afforded 37 as a white solid $(1.4 \mathrm{~g}, 97 \%):{ }^{1} \mathrm{H}$ NMR $\left(300 \mathrm{MHz}, \mathrm{CDCl}_{3}\right) \delta 1.49$ (t, $\left.J=7.0 \mathrm{~Hz}, 6, \mathrm{CO}_{2} \mathrm{CH}_{2} \mathrm{C}_{3}\right), 4.19\left(\mathrm{~s}, 3, \mathrm{OCH}_{3}\right), 4.47$ (q, $\left.J=7.0 \mathrm{~Hz}, 4, \mathrm{CO}_{2} \mathrm{C}_{2} \mathrm{CH}_{3}\right), 7.47$ (d, $J=$ $8.8 \mathrm{~Hz}, 2$, ArH), 8.16 (dd, $J=1.8,8.8 \mathrm{~Hz}, 2, \mathrm{ArH}), 8.37$ (br.s, 2, NH), 8.62 (s, 1, ArH), 8.90 (d, $J$ $=1.8 \mathrm{~Hz}, 2, \mathrm{ArH})$. Anal. $\left(\mathrm{C}_{25} \mathrm{H}_{22} \mathrm{~N}_{2} \mathrm{O}_{5}\right) \mathrm{C}, \mathrm{H}, \mathrm{N}$ 


\section{Elemental Analysis of the final products}

\begin{tabular}{|c|c|c|c|}
\hline \multirow[b]{2}{*}{ Compound No } & \multirow[b]{2}{*}{ Formula } & \multicolumn{2}{|c|}{ Analysis } \\
\hline & & Calcd & Found \\
\hline \multirow{3}{*}{10 (SR13650) } & \multirow{3}{*}{$\mathrm{C}_{21} \mathrm{H}_{16} \mathrm{~N}_{2} \mathrm{O}_{3} \cdot 0.2 \mathrm{H}_{2} \mathrm{O}$} & C: 72.49 & C: 72.83 \\
\hline & & H: 4.75 & H: 5.08 \\
\hline & & $\mathrm{N}: 8.05$ & $\mathrm{~N}: 7.65$ \\
\hline \multirow{3}{*}{35 (SR13661) } & \multirow{3}{*}{$\mathrm{C}_{27} \mathrm{H}_{24} \mathrm{~N}_{2} \mathrm{O}_{7}$} & C: 66.37 & C: 66.22 \\
\hline & & H: 4.95 & H: 4.86 \\
\hline & & $\mathrm{N}: 5.73$ & $\mathrm{~N}: 5.66$ \\
\hline \multirow{3}{*}{36 (SR13667) } & \multirow{3}{*}{$\mathrm{C}_{27} \mathrm{H}_{19} \mathrm{~F}_{7} \mathrm{~N}_{2} \mathrm{O}_{4}$} & C: 57.05 & C: 57.01 \\
\hline & & H: 3.37 & $\mathrm{H}: 3.47$ \\
\hline & & $\mathrm{N}: 4.93$ & $\mathrm{~N}: 4.66$ \\
\hline \multirow{3}{*}{37 (SR13668) } & \multirow{3}{*}{$\mathrm{C}_{25} \mathrm{H}_{22} \mathrm{~N}_{2} \mathrm{O}_{5}$} & C: 71.09 & C: 71.13 \\
\hline & & $\mathrm{H}: 6.71$ & H: 6.76 \\
\hline & & $\mathrm{N}: 10.39$ & $\mathrm{~N}: 10.38$ \\
\hline
\end{tabular}

Computational Analyses. Molecular modeling was performed using the SYBYL 7.0 software package (Tripos Associates, St. Louis, MO) on an IRIS 6.5 advanced workstation. Molecules were built within SYBYL, and bond angles and lengths were optimized. Atomic point charges were computed by using the Gasteiger-Htickel method. The global low-energy conformers of each molecule were generated by employing the RANDOMSEARCH option within SYBYL. The SYBYL RANDOMSEARCH function was used to locate the various energy minima available to each molecule by randomly perturbing torsions, minimizing, and eliminating duplicates. Hydrogen atoms were included during the optimization process but omitted for display.

Cell Proliferation Assay. The MCF-7 cells (ATCC) were routinely maintained in Eagle's minimum essential medium (MEM) supplemented with 10\% fetal bovine serum (FBS) and at $37^{\circ} \mathrm{C}$ in an atmosphere of $5 \% \mathrm{CO}_{2} / 95 \%$ air and $100 \%$ humidity. To initiate the assay, cells were seeded in 96-well plate at 2000 cells/well in $200 \mu 1$ of growth inhibition medium. After cells were allowed to attach for $24 \mathrm{~h}$, test compound was added to each well. Blank control cultures received vehicle alone. Incubation of cells was continued and medium with fresh test solution was added every other day. On Day 7, medium in each well was removed and $100 \mu 1$ of fresh medium was added followed by $15 \mu \mathrm{l}$ of tetrazolium dye solution (Promega, Madison, WI). The incubation was continued for 4 additional $\mathrm{h}$ and then $100 \mu \mathrm{l}$ of Solubilization/Stop solution was delivered to each well. During the $4 \mathrm{~h}$ incubation, viable cells converted tetrazolium component of the dye solution to formazan product which gives a blue color. The plate was kept at room temperature overnight and the blue color was measured at $575 \mathrm{~nm}$ on an ELISA plate reader.

Western blot analysis. Exponentially growing PC-3 cells were incubated in serum-free medium. $24 \mathrm{~h}$ later the cells were pretreated with SR13668 at indicated concentrations for $5 \mathrm{~min}$ before 
stimulation with EGF (final concentration: $10 \mathrm{ng} / \mathrm{ml}$ ). $2 \mathrm{~h}$ after EGF stimulation, PC3 cells were harvested and lysed on ice for $30 \mathrm{~min}$ in a buffer containing $50 \mathrm{mM}$ Tris- $\mathrm{HCl}, \mathrm{pH} 7.4,250 \mathrm{mM}$ $\mathrm{NaCl}, 25 \mathrm{mM}$ sodium phosphate $\left(\mathrm{Na}_{4} \mathrm{P}_{2} \mathrm{O}_{7}\right), 0.5 \% \mathrm{NP}-40,50 \mathrm{mM}$ sodium fluoride $(\mathrm{NaF}), 1 \mathrm{mM}$ sodium orthovanadate $\left(\mathrm{Na}_{3} \mathrm{VO}_{4}\right), 1 \mathrm{mM}$ DTT, $1 \mathrm{mM}$ phenylmethylsulfonyl fluoride, and protease inhibitors. The protein concentration in the lysate was measured (BioRad Protein Assay Kit) according to the manufacturer's instructions. Approximately $20 \mu \mathrm{g}$ of protein from each sample was resolved by SDS-polyacrylamide gel electrophoresis (PAGE) and transferred onto a nitrocellulose membrane filter. The membrane was then subjected to immunoblotting analyses using reagents in the Enhanced Chemiluminesence (ECL) Kit (Promega, Madison, WI) and the following antibodies: pAkt (Ser473), p-GSK3beta (Ser9) (Cell Signaling Technology, Inc., Beverly, MA) and actin (Sigma).

\section{Figure 1S. Effect of SR13668 on serum-stimulated Akt phosphorylation in PC-3 prostate cancer cells}

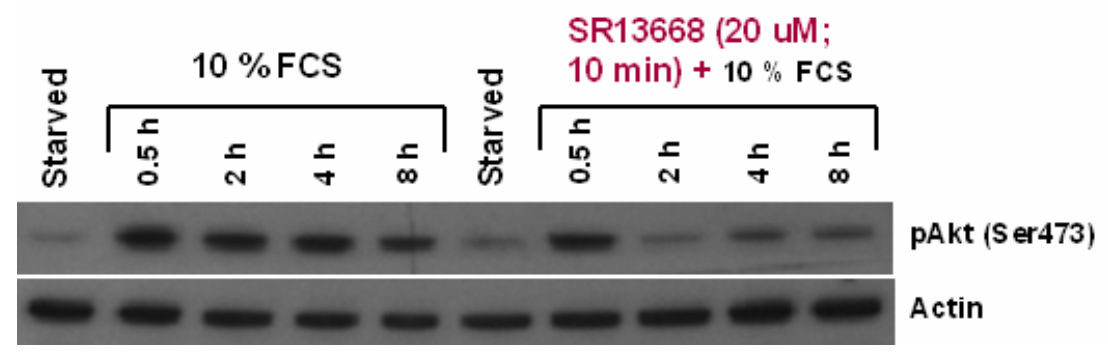

Figure 1S. Western blot analysis of pAkt in SR13668-treated PC-3 cells. PC-3 cells were quiesced in serum-free medium for $24 \mathrm{~h}$. Quiescent cells were pretreated with SR13668 at $20 \mu \mathrm{M}$ for $10 \mathrm{~min}$ before stimulation with $10 \%$ FCS. Western blot analysis was performed at various time points $(0.5,2,4,8 \mathrm{~h})$ after $10 \% \mathrm{FCS}$ stimulation.

\section{In Vivo Studies using ER ${ }^{+}$MCF-7, ER ${ }^{-}$MDAMB-231, PC-3, and SKOV-3 Carcinoma} Xenografts. Balb/c nude mice at 7 weeks of age were used for all the xenograft studies. To initiate the experiments, $5 \times 10^{6}$ cells suspended in $100 \mu \mathrm{l}$ of a mixture of medium/Matrigel $(1: 1, \mathrm{v} / \mathrm{v})$ were subcutaneously (s.c.) implanted in the right flanks. Mice were observed daily for tumor development. When the mean tumor volumes reached 70 to $100 \mathrm{~mm}^{3}$, mice began to be orally administered daily with various dose levels of SR13668 in $200 \mu 1$ of $0.5 \%$ hydroxypropylcellulose (HPC) in sterile saline solution. Control animals received vehicle alone. Mice were examined daily for tumor growth, and tumors volumes and body weight were measured twice weekly. Tumor volumes were measured using the formula $\mathrm{V}=\mathrm{L} \times \mathrm{W} \times \mathrm{H} \times$ $\pi / 6$, where $\mathrm{L}$ and $\mathrm{W}$ represent the longer and shorter diameters of the tumor and $\mathrm{W}$ represents the height of the tumor. For the ER+ MCF-7 xenograft study, estrogen pellets $(360 \mu \mathrm{g} / \mathrm{mouse} / \mathrm{pellet})$ were s.c. implanted to each mouse at 2 days prior to the implantation of cancer cells for the stimulation of cell growth. The estrogen pellets were implanted while mice were anesthetized by isoflurane inhalation. For the combination studies, SR13668 at various dose levels in $200 \mu 1$ of $0.5 \%$ HPC was orally administered daily alone or in combination with Taxol in $100 \mu \mathrm{l}$ of a mixture of DMSO/Chremophor EL/N2O (10\%/18\%/72\%). Taxol was administered intraperitoneally weekly and once daily for the first 4 consecutive days for PC-3 and SKOV-3 xenograft studies respectively. 